\title{
On the Hijab-Gift: Gift-Theoretical Considerations on the Ambiguities and Ambivalences of Islamic Veiling in a Diasporic Context
}

\author{
Anna-Mari Almila ${ }^{1 *}$, David Inglis ${ }^{2}$ \\ 1 University of the Arts London, UNITED KINGDOM \\ ${ }^{2}$ University of Helsinki, FINLAND
}

*Corresponding Author: a.almila@fashion.arts.ac.uk

Citation: Almila, A.-M. and Inglis, D. (2018). On the Hijab-Gift: Gift-Theoretical Considerations on the Ambiguities and Ambivalences of Islamic Veiling in a Diasporic Context, Journal of Cultural Analysis and Social Change, 3(1), 03. https://doi.org/10.20897/jcasc/2672

Published: July 20, 2018

\begin{abstract}
One of the most politicised topics across the social sciences today concerns Islamic veils (hijabs) and veiling. Scholarship has not yet sought to illuminate specific veiling phenomena in light of gift theory, begun by Marcel Mauss in the 1920s. We focus on how particular Islamic women - in this case, in diasporic Muslim communities in Finland - give hijabs to each other as gifts. We use gift theory to understand the significance of such acts, unpicking the subtle power dynamics at work. We seek to throw new light on both micro-level, individual-to-individual aspects of bijab-gifts, and on the more macro-level factors bound up with these acts of gifting. A bijab-gift is potentially deeply ambiguous, as well as powerful, because of the multiple layers of significance at work within it, encompassing factors including religious precepts, family and community norms, and commoditised sartorial fashion objects. Social relations involving such gifts can be deeply ambivalent. Female gift donors are seen to be able to shape the thoughts and actions of recipient women in various ways, in terms of: how and why they wear the hijab; which types of hijab, and which kinds of religious observance, they adopt; and the ways in which they understand their own motivations in the hijab's adoption. By bringing hijab and gift issues into dialogue with each other, we highlight the complex and subtle ways in which gifts can operate today.
\end{abstract}

Keywords: gender, diaspora, gifts, Muslim, hijab

\section{INTRODUCTION}

One of the most politicised topics across the social sciences today concerns Islamic veils - hijabs - and veiling. Multiple perspectives have been developed to understand many different aspects of these phenomena (see Almila, 2017 for a comprehensive overview). Yet to our knowledge, scholarship has not yet sought to illuminate veiling phenomena in light of gift theory. The latter was begun by Marcel Mauss in the 1920s, and there has been almost a century of extensions, refinements and rejections of his original claims about the nature of gifts and gift-giving. We focus on how particular Muslim women give hijabs to each other as gifts. We use gift theory to understand the significance of such acts. We seek to throw new light on both micro-level, individual-to-individual aspects of hijabgifts, and the more macro-level factors bound up with these acts of gifting. In so doing, we hope to offer fresh insights into the nature both of hijab-wearing, especially in terms of dynamics in Muslim diaspora communities, and of the complicated ways in which gifts operate today, including in such communities.

The key themes running throughout the paper are ambiguity (of certain clothing objects, to be used as hijabs, that are given as gifts) and ambivalence (in terms of the feelings and perceptions of the women handling those objects 
in and through gift-giving, and of the social relations operative between female donors and receivers). This is so in multiple, mutually informing, ways, and at a number of levels. According to gift theory, gifts are by their nature ambiguous entities for various reasons, and acts of gift-giving can be very ambivalent. So too are hijabs, for they embody multiple values, encompassing religious, ethnic and gender norms, as well as being sold on markets as commodities.

A hijab is not just a garment, even though it is widely thought to be some sort of scarf. A scarf is just one possible variant. Instead, the term hijab refers more widely to 'modest' forms of dress which observe certain religious precepts. Practically any suitable garment, bought anywhere, and coming from any kind of producer, avowedly 'Muslim' or not, can be used as a hijab. Many garments used as hijabs are produced today by the global Islamic fashion industry, which is also ambiguously located between the realm of constant change, commodities, capitalism and profits, and the world of religious piety and observance. Therefore, a bijab-gift is deeply ambiguous, because of the multiple layers at work within it, each of which are themselves marked by complex ambiguities. The ways in which hijabs are discussed, and the manners in which acts of giving them are made sense of, by Muslim women, are also ambivalent, in part because these sometimes involve the mixing of more religious and more secular logics. This is especially marked in diasporic contexts and Muslim-minority locations.

The paper concerns itself with gift-giving in one Muslim diasporic context, namely contemporary Finland. It draws upon data gathered during 10-month ethnographic fieldwork in the Greater Helsinki area (encompassing the urban areas of Helsinki, Espoo and Vantaa) carried out in 2011-12. While a much larger data set, involving interviews with 46 Muslim women - Somali, Finnish converts to Islam, Shia Iraqi, Shia Iranian, and Shia Afghan was collected, this paper focusses on six women. Nura ${ }^{1}$ is a Sunni Somali woman in her mid-twenties, who holds conservative religious views and dresses accordingly. She came to Finland in her pre-teens, having previously lived in Somalia and Saudi Arabia. Aisha is a Finnish convert to Islam in her mid-twenties. She converted when she was 18, and has previously lived in Saudi Arabia with her Arab husband. Miriam is a Finnish convert to Islam, and she is in her mid-twenties. She had lived as a Muslim for four years, and did not have any contact with Finnish Muslim communities. Afra is a Shia Iraqi in her late twenties. She arrived in Finland as a teenager. Khadija is a Finnish convert to Islam in her early 60s. She had converted two years prior to the interview. Zaynab is a Somali woman in her late twenties, who arrived in Finland in her early teens. She veiled only as an adult and has moderate views on religion.

We first turn to consider Mauss's original ideas about gifts and gift-giving, and how these have been extended and criticised over the years. Then we set out the various ways in which capitalism and the globalized Islamic fashion industry impact upon hijabs and Muslim women's gift-giving. After that, we reflect upon how gifts of hijabs are connected both with the maintenance of existing Islamic diaspora communities, and with the conversion of non-Muslims into the status of affiliated believers. The penultimate section concerns how patriarchal social relations are bound up with hijab-gift practices. The final part concerns the ambiguities and ambivalences to be found in Muslim women's giving away of clothes, including hijab-related ones, for Islamic charitable purposes, or for other, more apparently secular reasons. Overall, we highlight the strikingly high levels of ambiguity and ambivalence that are often involved in all these practices.

\section{THE THEORY OF GIFTS AND GIVING}

Since the first publication in 1925 of Mauss's Essai sur le Don, translated into English as The Gift (Mauss, 1970), there have been many criticisms, refinements and extensions of his original claims, the main dimensions of which we consider here. Generally speaking, Mauss and later commentators have focused on three major issues: 1) the power of gift-giving to create social relations and communities, 2) the special qualities of objects which accrue to them when given and received as gifts, and 3) the highly ambivalent nature of gifts and gift relationships (For overviews, see Schwartz, 1967, Hyde, 1983, Appadurai, 1986, Parry and Bloch 1989, Carrier, 1995, Godelier, 1996, Titmuss, 1997, Godbout and Caillé, 1998, Graeber, 2001, Mirowski, 2001, Osteen, 2002, Komter, 2005, Pyyhtinen, 2014).

Gift relationships are seen by Mauss (1970: 18) as involving a contradictory combination of 'intimacy and ... fear which arise[s] from [the] reciprocal creditor-debtor relationship', which is central to giving and receiving gifts. Gifts operate ambiguously in the spaces between sets of opposed values (Derrida, 1992). These include: kindness and aggression, disinterestedness and selfinterest, co-operation between individuals and conflict between them, care for others and endeavours to control them, giving away wealth and making personal gain, the power of the giver over the receiver (and vice versa), inner volition and social obligation, and interior piety and the social display of virtue. Gifts are therefore deeply ambiguous phenomena (Skågeby, 2013). We can add to these considerations by noting the ambiguity of the interplay between religious and secular logics which arises in Islamic diaspora contexts strongly influenced by the operations of the

1 All the names are pseudonyms.

$2 / 17$

C 2018 by Author/s 
capitalist economy and global politics. A hijab is already an ambiguous object, but when it is given as a gift, various further levels of ambiguity accrue to it, as we will see.

Having examined Franz Boas's ethnography of the Kwakiutl people of the North American Pacific Coast, and Bronislau Malinowski's study of the Melanesian kula ring, Mauss discerned among these groups elaborate social systems which involved giving gifts and repaying them by making other gifts. He deduced that giving gifts is a bedrock of human sociability per se, at least in pre-modern societies, but possibly 'modern' ones too (Chanial, 2014). The ways in which objects are handled as gifts, and circulate within and between groups, both embody and reproduce the social relations of those groups (Addo and Besnier, 2008). Gift practices help to create communities and relations between communities. A chain of gifts in exchange for Mauss does not usually involve only a simple dyadic relationship between two individuals, but rather also involves groups of individuals giving to other groups. Even when one individual gives a gift to another, the community - or communities - that each belongs to may be symbolically present. More recent scholarship has shown that gift-giving can construct and reinforce kinship and community ties which otherwise might be dissipated by physical distance and lack of ongoing direct face-to-face contact between the parties involved (Caplow, 1982). Gift-giving has also been seen to create group boundaries, and to structure social relationships within those boundaries (Frith, 1967, Hyde, 1983, Weinberger and Wallendorf, 2011, Cheal, 1988, Godbout and Caillé, 1998).

A crucial issue for Mauss concerns the mixture of 'obligation and spontaneity in the gift' (Mauss, 1970: 63). Gifts, 'which are in theory voluntary, disinterested and spontaneous ... are in fact obligatory and interested'. The gift may be apparently 'generously offered ... [but] the transaction itself is [in fact] based on obligation' (1970: 1). Surface-level generosity can, and usually does, mask more subterranean but forceful forms of obligation. Gift relations are therefore ultimately power relations (Garces and Jones, 2009).

According to Mauss, the recipient of the gift is potentially under two forms of obligation, sanctioned by the social group to which at least the giver, if not also the receiver, belongs. First, there is a tacit but powerful obligation to accept the gift being offered. 'Refusing to accept [is] the equivalent of a declaration of war; it is a refusal of friendship and [social] intercourse' (1970: 11). A person 'does not have the right to refuse a gift ... [because to] do so would show fear of having to repay ... admitting defeat in advance' (1970: 39). '[Y] ou accept ... because you mean to take up the challenge and prove that you are not unworthy' of the gift you are being offered (1970: 40).

Second, there is an obligation for the recipient to reciprocate the initial gift by in turn giving the original donor another gift, the counter-gift, after a certain amount of time has passed (1970: 5, 34). The intimate nature of the donor-recipient relationship fundamentally goes together with the risk of 'losing face' if one cannot adequately reciprocate the initial donor (1970: 38). To be unable to proffer an adequate counter-gift is to lose honour, social status and self-esteem. Strong social sanctions are attendant upon someone who fails to return a gift. The countergift usually must be of equal or greater value to the initial gift (1970: 63). Such a return gives the initial recipient 'authority and power over the original donor, who now becomes the latest recipient' (1970: 10). The counter-gift therefore shifts the balance of power back towards the initial recipient. The countering of the initial gift is likely to provoke in turn a further series of gifts and counter-gifts between both parties, a process that may last a long time, possibly even for life. Both donor and receiver are pulled into a social system that is given life, and potential permanence, by the to-ing and fro-ing of gift-exchange (1970: 18, see also Douglas, 1990, Belk, 1988). This explains why it is in 'the nature of the gift in the end to be ... its own reward' (1970: 34). The initial expenditure by the first donor leads to a chain of counter-gifts, bringing various benefits to the original donor, and possibly also to the initial recipient.

According to Mauss, the donor retains 'a magical and religious hold over the recipient' (1970: 10), as the object gifted is felt to be invested with some of the spiritual essence of the donor. The spiritual element of the gift is one of its crucial features. When giving a gift, 'one gives away ... a part of one's nature and substance, while to receive something is to receive a part of someone's spiritual essence' (1970: 10). As that essence inheres within and lingers around it, then the gift which is received is 'owned by the recipient', but 'the ownership is of a particular kind ... It is ... a pledge and a loan ... a deposit, a mandate, a trust' (1970: 22). A received gift therefore is never just a simple object devoid of significance. It is rather a powerful reminder of someone else, and possibly of the social group that stands behind them too (Carrier, 1991, 1995). It is a potent object, charged with the presence of the donor, around which a certain kind of animated power hovers, and through which the recipient's obligations to the donor - and vice versa - are expressed and maintained (Keane, 2006).

The gift is also fundamentally connected to forms of social power, for it is potentially a means of controlling other people. The obligations involved in the gift relationship entail that the initial recipient comes into the gravitational pull of the initial donor, and perhaps also of the group to which the donor belongs, or which they present themselves as a representative of. Mauss seems to imply that there are no 'free gifts', because obligations, to the donor, and perhaps also the group they are part of, are always incumbent upon recipients (Douglas, 1990). For one major interpreter of Mauss's ideas, Georges Bataille (1991), gift-giving is pre-eminently a hidden form of power and control. The donor gains advantages over the recipient, and perhaps also over an audience which 
witnesses the gift-exchange, by the apparently altruistic act of giving things away (Kosalka, 1999). The socially dominant donor (Sahlins, 1972) can potentially impose a debt that the dominated recipient may never be able to repay fully, thereby imposing their right to keep the recipient in permanent subordination (Blau, 1986, Caillé, 2005, Chanial, 2014). This is one variant of the 'dark side' of gift-giving obligations (Sherry, McGrath and Levy, 1993), of which there are also 'evil gifts' that express and create antagonisms (Vaughn, 1997), and the contaminating possibilities of 'spoiled' gifts (Belk, 1988). Conversely, some have argued that observation of norms of reciprocity can prevent the powerful from fully exploiting their position of advantage, with wholly one-way flows of gifts, from powerful to less powerful actors, not being tolerated in at least some societies (Gouldner, 1960, Sahlins, 1972).

Later scholars have pointed out that the precise nature of power in a gift relationship depends on whether donor and recipient are regarded, by each of them and/or by a wider peer group, as of equal social status or not (Gouldner, 1960). Wide status differentials between the parties can markedly affect gift-giving dynamics, involving factors such as class, ethnicity and gender hierarchies (Firth, 1967). It is also significant whether gifts are exchanged by participants within communities - themselves riven by multiple power and status differentials - or across community boundaries, with different groups enjoying variable levels of social advantage and disadvantage (Herrmann, 1997). The gift is potentially a subtle but powerful means by which a group, through the gift-giving of one of its members, can begin to instil its values into the mindset and behaviour of a recipient if they are from another group, or can reinforce its values onto a recipient who is already a group member (Mauss, 1970: 73). The latter situation would apply in cases where donors may perceive recipients to be exhibiting less strongly than they think desirable the acceptable attitudes and practices of the group, or are acting in ways perceived to be somehow deviant.

Later scholars have interrogated Mauss's assumptions about the intentions and motivations of donors and recipients. Instead of assuming donors always possess hidden or unconscious desires to control recipients, contemporary scholarship tends to emphasise the mixed motives at work in gift giving, locating these on various spectra. One such spectrum is that between high intentionality and totally unconscious motivations. Another is that between high levels of manipulation and donors having no desire to gain anything from the gift (Herrmann, 1997, Elder-Vass, 2015). This suggests, contra Douglas's (1990) interpretation of Mauss, that totally disinterested gifts - which give the donor pleasure in the act of giving itself, beyond any ulterior motives and expectations of reciprocation - are at least theoretically possible (Godbout and Caillé, 1998). There may exist forms of gift-giving from which Mauss's emphasis on the compulsion to reciprocate is absent (Testart, 1998, Mirowski, 2001). One can also locate specific acts of gift-giving on a continuum between low status, high frequency quotidian events (e.g. sharing lunch with a work colleague), through to low frequency, high status events socially marked as somehow special (e.g. gifts given at a wedding) (Douglas and Isherwood, 2006).

In Bourdieu's $(1977,2000)$ influential formulation into phenomenological language of gift-giving practices, these are usually neither entirely interested nor wholly disinterested, but rather involve a mixture of the two elements. The precise mixture is shaped by the interplay of the habitus of each party (Silber, 2009). Actors usually do not think in terms of ideal types of 'gift' and 'commodity' (Gregory, 1982 - and see below), but they normally combine these categories in ways that are not perceived by them as contradictory. The disinterested aspect of giving a gift can be actively created by the donor suppressing any sense of calculation in the giving act. Calculation can also be disguised by the initial recipient by not returning the counter-gift immediately, a delay in reciprocation making the counter-giving seem free of instrumental considerations.

Mauss (1970: 39) notes that 'in certain circumstances ... a refusal [of a gift] can be an assertion of victory and invincibility'. A refusal to receive a proffered gift is possible if the putative recipient has both the boldness and social resources necessary to resist the blandishments of the putative donor, refusing their overtures to enter a giftgiving relationship, and being content to risk giving potentially grave offence. For some - probably more socially privileged - actors, refusing a gift, or refusing to reciprocate a gift already accepted, is a possibility, albeit possibly still a risky one (Callon and Law, 2005). If a recipient gives back to the donor an exactly similar type of object to the one that $\mathrm{s} /$ he has previously received, that could be read as a refusal by the recipient to accept the initial gift. To avoid such stand-offs, the counter-gift is often an object of a very different type from that which was given in the first place (Bourdieu, 2000). More generally, contemporary economic sociology stresses the ambivalence and potential messiness of gift-giving, because the different parties may attribute different meanings to the same gift and act of giving. Mismatches in expectations - such as when you give me an object defined as a gift, and I think it is just an object like any other that I can resell on eBay - can create serious ruptures between people. Ruptures are more likely when the parties involved do not have shared habitus and cultural expectations (Lainer-Vos, 2013).

Over the last several decades, feminist scholars have subjected Mauss's formulations to critique and reevaluation, especially regarding questions to do with how female-to-female gift-giving relationships might work (Leacock, 1981, Strathern, 1988, Weiner, 1992). They have argued that Mauss's account is colonialist, gender-blind and gender-biased, as are understandings of gifts and gifting derived from it, notably that of Lévi-Strauss (Bracken, 
1997). Male authors are said to have uncritically projected onto gift-giving in general, and women's roles regarding gift relationships in particular, some of the taken-for-granted gender biases of the societies they themselves are part of (Joy, 2013).

Empirical investigations have revealed that in some contexts women tend strongly to locate specific objects, including gifted ones, within social relationships ('My aunt gave me this scarf for my birthday'), while men tend to talk more egocentrically about objects, under-playing or omitting to mention their embeddedness in social relationships, including gifting relations (Csikszentmihalyi and Rochberg-Halston, 1981). Women in some societies are also more likely to choose and pass on gifts. The buying of birthday presents, for example, is often delegated to them because such activities are regarded as insufficiently 'masculine' for men typically to engage in (Cheal, 1988). Some researchers have also discovered evidence of gifts given by men being more glorified and formalised, in contrast to the more hidden and informal gifts given by women, especially to each other (Chanial, 2014). This points to the issue of unrecognised and under-valued gifts being particularly associated with female donors and recipients (Caillé, 2007). Some observers have noted that across many cultural contexts, women tend to struggle more than men to refuse gifts, or to escape from obligations to reciprocate gifts, these phenomena being indicative of the presence of broader patriarchal social relations (Folbre, 2001).

We return to issues of gender below. There have also been various other developments in debates about the nature of gifts and gift-giving in the decades after Mauss's original intervention. We will set out the relevant features of these debates in the substantive sections of the paper which follow, connecting the theory to the empirical data in each case.

\section{CAPITALISM, THE ISLAMIC FASHION INDUSTRY, AND LOGICS OF GIFT-GIVING}

We now turn to consider the nature and role of gifts in modern capitalist socio-economic systems. This raises issues about the special qualities objects perceived as gifts are thought, by both actors and analysts, to possess. Mauss drew a strong distinction between gift-giving and capitalist commodity exchange relations. In non-capitalist economies, objects are seen by Mauss to be thoroughly bound up with the persons who make and/or give them. The personality of the maker and/or giver is felt to inhere within the object in profound ways. This stands in stark contrast to the logic of capitalist economic exchange, which emphasises monetary price, and through the cash nexus disentangles the object-as-commodity from those who make it or sell it on to a consumer (Appadurai, 1986, Kopytoff, 1986). Once the capitalist consumer has purchased the object, it is (usually) wholly and unambiguously 'theirs'. For Mauss, objects operating as gifts work differently. The object that is given as a gift is transformed from being a mundane material thing into a special sort of entity. The process of gifting and counter-gifting involves not capitalist economic exchange of pure commodities, but rather 'a pattern of spiritual bonds between things which are to some extent parts of persons' (Mauss, 1970: 11).

Later commentators have frequently commented on Mauss's apparently contradictory views on the sociohistorical ubiquity of gift-giving institutions. He seems to have oscillated between two possibilities. The first involved regarding gift-giving as a social system-building mechanism which operated only in pre- or non-modern contexts, and which had died out for the most part in Western capitalist modernity, leaving only dim vestiges behind. The second option was to regard pre-modern gifting practices as still alive and well in modern capitalist social orders, operating either along-side, or at least in the interstices of, capitalist forms of commodity exchange (Godbout and Caillé, 1998, Shershow, 2005).

This is an issue that continues to be debated today (Elder-Vass, 2015). Some scholars (notably Cheal, 1988) have argued that the kinds of gift systems, encompassing whole communities, which Mauss had in mind are purely archaic, and have been replaced by forms of gifting involving individualistic persons in limited dyadic relations, giving each other presents on voluntary rather than obligatory bases. This position has been much criticised in the contemporary literature on gift-giving. It assumes a simplistic binary division between modern capitalist exchange relations (under which gifting has allegedly been wholly subsumed) and gift-giving chains and systems, which are assumed to be wholly pre- or non-modern in nature. This division ignores the ongoing presence of system-building, gift-giving chains operative today, not only outside of contemporary capitalist exchange relations, but also within them (Bird-David and Darr, 2009, Adloff and Mau, 2006). Most contemporary scholars who study gift relationships would probably say that gift-giving and the relations it creates can still operate according to their own specific logics, irreducible to capitalist exchange principles, even within contexts that are strongly informed by capitalist socio-economic relations. Objects given as gifts are often not treated by either donors or recipients as pure commodities that can be disposed of blithely in a marketplace setting.

Claims as to gift-giving in modern capitalist societies being a purely individualistic exercise are also charged by critics with being deeply ethnocentric, taking as their model the (post-)Christian phenomenon of Christmas gifts being subsumed under capitalist consumerist logics. The model ignores how different ethnic and religious groups around the world continue to engage in the sorts of practices that build the sorts of systems and chains of gift- 
giving which Mauss had in mind (Bird-David and Darr, 2009). This point of course applies to Muslim diasporic communities in Muslim-minority countries. This is especially so at a time when the globalized logics of capitalist consumerism are intertwined in complex ways with forms of Muslim observance, as in the case of the increasing commercialisation of festive periods like Ramadan (Sandikci and Omeraki, 2007).

Since Mauss's time, both anthropologists and sociologists have sought to complexify his often rather rigid conceptualisations of the relations between commodity-objects and gift-objects. A clue here has been Mauss's original contention that any object can potentially take on the special qualities of a gift, if it is given to a recipient in the spirit of the gift (Mauss, 1970: 12). So powerfully can objects be invested by donors - and recipients too - as possessing the special qualities that gift-objects possess, that for those in a gift-giving relationship, material objects can come to seem to have 'a virtue of their own which [itself seems to] cause ... them to be given and [which in turn] compels the making of counter-gifts' (1970: 37). Once objects are defined by the parties involved as gifts, those 'things have personality' (1970: 44), and are felt to have a special sort of resonance and charisma. They leave various sorts of traces, invisible yet tangible, on both donors and recipients (Hyde, 1983).

Following up on these suggestive remarks, contemporary anthropologists have shown how within capitalist socio-economic contexts, specific objects can shift in and out of particular social categories, by being commodified, de-commodified or re-commodified at different points in time. By the same token, an object can at one point be defined as a gift, and at another time lose that special status and become just one commodity among multiple others (Appadurai, 1986, Kopytoff, 1986). Economic sociologists have also shown how particular individuals can work to define objects as either gifts or commodities - for example, taking price tags off, or wrapping them in special paper, processes which Zelizer $(1996,2000)$ refers to as 'earmarking'. A focus on such micro-level practices suggests a shift in analytic focus, away from gift-giving relations as system-building mechanisms, which the ethnographic material that Mauss drew upon suggested, towards understanding gifting as a set of more localized, contingent, practical organizational accomplishments (Lainer-Vos, 2014: 482).

Turning now to the case of the hijab, this is an object that is markedly ambiguous in terms of the interplay of religious principles and capitalist commercialisation processes. The hijab itself is not just any garment, but is rather a materialised form of female modesty, encompassing dress, comportment, behaviour and the purity of thought and intention (Almila, 2018). This makes the hijab's relationships to sartorial fashion and the fashion industry complicated, and often for the actors involved, problematic too. Many garments used to construct 'modest' forms of dress today are made by the globalized and trans-national Islamic fashion industry, which makes products ranging from simple scarves which retail at very low prices, to extremely expensive designer garments (Kiliçbay and Binark, 2002, Sandikc1 and Ger 2007, Gökarıksel and Secor, 2013).

This industry is like any other fashion industry in that it produces sartorial commodities for trans-national markets and consumers. But it is unlike other clothing industries because of its explicit and self-consciously 'religious' dimensions. Its products are never just pure capitalist commodities, as most other clothing fashion goods are, because they combine the characteristics of products for sale as well as being objects of religious significance. This is reflected in the fact that there are multiple ongoing debates today, among actors and analysts, about the relationships between Islam and sartorial fashion. These include: whether Islamic fashion shows are acceptable on religious grounds (Jones, 2010a, Sandikc1 and Ger, 2007); whether enhancing one's appearance through fashionable clothes, rather than seeking to create less attention-drawing ways of dressing, is appropriate for a religiously observant woman (Sandikc1 and Ger, 2005); and whether the wasteful consumption often associated with the global fashion industry is religiously acceptable (Moors and Tarlo, 2013).

The partly religious and partly commercialised, commoditised character of the hijab makes it deeply ambiguous in and of itself, and women who wear more 'stylish' forms of hijab have to negotiate carefully the forms of ambivalence promoted by its simultaneously commercial, fashionable and religious dimensions (Jones, 2010b). This ambiguity is augmented when a hijab is rendered as a gift. Since a gift is already potentially a highly ambiguous phenomenon, a bijab-gift is potentially an even more markedly ambiguous entity, and the acts of giving and receiving it are possibly marked by deep ambivalence. When a bijab-gift is given, like any other non- or de-commoditised gift, it contains the lingering presence of the charisma of the donor. But in addition, the fact that it was already predefined as having religious significance, even at the point when it was purchased as a commodity, means that it also carries strong associations of religious piety.

Therefore the recipient of such a gift faces an object charged with multiple layers of significance. There is significance deriving simultaneously from the donor (involving an individual-level obligation to receive and reciprocate, encompassing relations and overtures of friendship), and from the donor's (e.g. ethnic) group, and from the donor's religion (with both the latter factors involving more macro-level senses of obligation). One might expect that a recipient may be particularly reluctant to refuse a gift so potentially powerfully charged, especially when its multiply-layered character has rendered it so apparently strongly de-commoditised and invested with surging levels of significance. The level of potential obligation to receive and reciprocate such a gift would be correspondingly high. A bijab-gift is simultaneously very multivalent, and also potentially very powerful as a means 
of a donor influencing a recipient. Such power in large part rests in, and is made possible by, the multifaceted and ambiguous nature of the gifted object itself. The object is charged with and expresses multiple types of social relationship: friendship, family and group membership, religious affiliation, and possibly other types too. A bijabgift therefore need not be expensive in money terms in order to be very richly endowed in significance. Even a garment bought by a donor for very little money - the type of object donated in most of the cases outlined in the examples below - can take on huge significance, and be rendered into a powerful means of communication, bonding and influence.

\section{GIFTS, CONVERSION AND COMMUNITY MAINTENANCE}

We will now turn to think through such issues in terms of empirical data about a particular diasporic social situation. Mauss's original formulations point towards gift-giving's potential roles as a means of creating and stabilizing social relations of many types, including dyadic relationships between individuals, family and extended kin relationships, and multiple forms of group membership, including in religious communities. Gifting relationships in more settled social contexts can counter quotidian processes of the atrophying of social relations. For example, sending a present to a geographically distant person at Ramadan reminds them of the donor's role as relative or friend, revivifying a relationship that might otherwise deteriorate through unintentional neglect. In more unstable social contexts, gift-giving can help stabilize community relations and provide senses of both group solidarity and of 'normality' in the face of challenging external social forces. These are particularly important means to deal with the uncertain life-conditions faced by many diasporic communities (Hogan, 2010).

Given it is now almost a century old, is Mauss's thinking about gifts outdated in an age of widespread migration and diaspora, where certain communities, including Islamic ones, have become ever more trans-national and spread across multiple terrains? Cross-border gifting relationships, stretching over long geographical distances and across cultural and political boundaries, were in fact already encompassed by Mauss. This is partly because his reflections on gifts were based to some extent on thinking through the implications of gifting across long, even oceanic, distances in Pacific Ocean societies, as this was described by Malinowski. In these sorts of relationships, matrimonial gifts were an integral part of alliances between different groups that were forged through intermarriage (Hénaff, 2010). Mauss's points about gifts and gifting can therefore be relatively easily applied to transnational, cross-border social relations and diasporic conditions of the present-day (Addo and Besnier, 2008). Giftgiving within and across various sorts of borders (political, cultural, linguistic, religious, etc.) can both reflect existing, and produce new, forms of social participation, affiliation, and group belonging. This can make group membership both practicable and meaningful for individuals, especially those who may be very physically distant from each other (Lainer-Vos, 2014).

Writing about contemporary gifting practices in Tonga, Addo and Besnier (2008: 40) point out an issue that affects multiple groups across the world today, including diasporic ones. A 'proliferation of conservative objects and practices' - in the Tongan case, traditional woven mats, and in the case under discussion here, some types of hijab - can happen 'at the same time as agents' lives are increasingly steeped in capitalism, consumption and modernity'. Things and practices taken by those involved to be 'traditional', if not indeed 'conservative', are bound up in complex ways with capitalism, consumerism and globalized elements of modernity. Such objects, and the relations within which they are embedded, are stimulated, revivified and reworked in and through macro-level forms of social change, as these are played out in micro-level contexts.

The power relations pertaining between and within different communities in diasporic contexts are multiple and complex. It is obvious that most ethnic majority people in Finland enjoy certain benefits that are not available to the members of the Muslim minority, who are marked as 'different' for reasons of both ethnicity and religion. As gift-giving is fundamentally bound up with power relations, it is important to consider the subtleties of different gift-giving pairings: Muslim to Muslim, Muslim to non-Muslim (including potential convert to Islam), and non-Muslim to Muslim or convert Muslim. Different dynamics operate in each of these cases, as we will now see.

It is well known that in diaspora contexts, different social dynamics are at work than in the home country (Moghissi, 2003). To retain, or recreate, one's cultural heritage is of vital importance in a situation where community borders may be under constant threat of dissolving. But the retention of perceived heritage may take on more conservative and/or stricter forms than would be necessary or usual back in the homeland. The transformation of elements of Somali religiosity is one example of this. Traditionally, Somalis have practised a form of Islam that was somewhat Sufi-influenced, involving certain mystical elements. But among the younger generation, especially in the diaspora, such 'traditional' forms of Islam are much rarer today, and new forms of faith have been established. One of these tendencies is related to the conservative form of Islam that is often called 'Salafi'. Salafism is a form of faith that seeks to 'purify' Islam from what it regards as 'external' cultural influences, with the aim of practising religion in a purer 'original' form (Ahmed, 2011). This school of thought is strongly connected financially and ideologically with Saudi Arabia, and is widely considered as 'conservative' or even 'radical' by many Muslims and 
non-Muslims alike. This is a school of thought that is very supportive of more conservative forms of female dress. Supporters of these more conservative ideas and practices also often participate in Dawah, the 'calling to Islam', an invitation to believe in Islam and to practise its tenets, which is directed to both Muslims and non-Muslims.

There are ongoing power struggles within Muslim communities in Finland, in which both the defenders and rejecters of more conservative forms of dress use religious arguments to justify their respective positions. The debates draw upon and amplify a particular sort of ambivalence, that pertaining between 'choice' and 'free will' (Almila, 2018). It was common in the empirical research undertaken for this paper to find that the same woman would say apparently contradictory things in one interview: on the one hand, that the hijab is only meaningful if it is chosen through an individual's free will; on the other hand, that the hijab, or a certain form of it, is simply obligatory for a believing woman, beyond any choices she might make.

It is in the light of this ambivalence as regards choice and free will that we can read the gift-giving which Nura, a Somali in her mid-20s, engaged in.

Just this summer I gave up a khimar ${ }^{2}$ I've worn for many, many years. It was very dear to me... But... in my opinion it was useless to leave it in the closet; I got a migraine and I couldn't [wear it]. Someone else wanted to start [wearing] the [khimar], which is a great thing if another Muslim wants to cover herself more. I was very glad [and] I gave it to her.

Nura experiences the joy of giving a gift in an apparently disinterested way. But at the same time, her gift-giving is part of wider discursive struggles within her community. These involve defining the appropriate comportment of female bodies, according to stricter or looser interpretations of Islamic precepts. Nura is strongly influenced by stricter Salafist ideas, and often tells her younger sisters that they should cover up more. A khimar is not exclusively a Salafist garment, but it is sometimes associated with more conservative religious observance. By giving one to another woman, Nura invites the recipient to follow a stricter dress code than presumably the recipient currently observes, and in so doing to make a broader practical and ideological commitment to a more conservative interpretation of Islam. Nura interprets her act as a disinterested one. If the gift was indeed given in that spirit, it may have been particularly difficult for the recipient to refuse such apparent generosity. It is through the means of an apparently sincere performance of generous gifting that the invitation to observe a stricter lifestyle might become particularly compelling for the recipient. This indirect approach may well work better than a direct demand from the instigator, here Nura, for the recipient to wear more covering styles of dress. An imposition on the other person is finessed by garment gifting so that it seems not to be such.

A Somali woman in Finland has far less power either to reject an apparently disinterested gift from a community member, or to take it but never subsequently wear it, than has a Finnish woman. This applies whether the latter is a non-Muslim or a convert to Islam. For the Somali, peer reactions matter much more than for Finns, for her dependence on the goodwill and approval of the community is markedly greater. For a Finnish Islamic convert, there are usually less strong obligations both to receive a hijab-gift and to wear it later.

This is especially so if a woman is in an early stage of her conversion career, as we can see in the case of Aisha, who was 18 when she converted. She said how, after reading the Qur'an and believing it to be 'the truth', she sought to learn more about the practicalities of living as a Muslim. Testing out the religion before taking the major step of affiliating herself with it, she sought to learn how to pray. Through an internet discussion forum, she made the acquaintance of a Somali Muslim woman of her own age, and learned more from her about everyday life as a believer.

I visited her a couple of times and she showed me how to pray and gave me a scarf and then an abaya ${ }^{3}$. [...] So, I actually started to wear them and pray before I had said Shahada [the declaration of belief a convert must make].

In this subtle invitation to religious conversion, which the donor's gift can be interpreted as involving here, the practical value of the gift is significant. A Muslim woman must veil when she prays. By gifting garments that make veiling, and therefore praying, possible for the new convert, her conversion through repeated religious acts is made more likely. Scholars have argued that formal affiliation to a religion is a relatively small factor during an individual's conversion career (Gooren, 2007). To develop what peers will regard as a properly religiously observant disposition, the patterns of both religious knowledge and practice must be transformed (Rey, 2008). The bijab-gift can very much help to encourage the potential convert along the path to affiliation. The counter-gift here can be

2 The khimar is 'a headcover that covers the hair and extends low to the forehead, comes under the chin to conceal the neck, and falls down over the chest and back' (El Guindi 1999: 130-1).

${ }^{3}$ An abaya is 'a long-sleeved robe that covers the body from the neck to the floor' (Lindholm 2010: 253). 
understood as the act of conversion itself, or rather the multiple small acts that together make up the overall conversion career.

It should be added that Aisha, the Finnish convert, would have encountered little risk if she had chosen either to reject the gift, or to take it without feeling any sense of obligation and then never actually wear it. She was not at all dependent on the Somali woman or that woman's community. Even with the decision fully to become a Muslim, Aisha could have chosen some other ethnic or faith community through which to start practising her religion. She could also have become a Muslim with no specific community connections. Her position as a Finnish convert meant that she had much more room than members of ethnic minority groups usually have, both for actively seeking out possible informants (who might become gift donors), and for deciding whether to accept their gifts or use them in the ways the donors intended. A Somali recipient would very likely have felt underlying obligations to deal with members of her own community, to accept their gifts, and to reciprocate their donations somehow, such as by dressing in the manner implied as desirable by the donor.

Many converts to a religion find that their relations with the surrounding society change radically after their conversion, particularly if, in the Islamic case, they choose to veil (Franks, 2000). For another Finnish convert, mid-twenty-something Miriam, who is married to a Jordanian man, the changes were less radical than for some converts. This is partly because she chooses to wear as a hijab a scarf that is not immediately recognisable as 'Islamic'. While she has blogged about her faith and her religious transformation, she has not otherwise talked about it openly, not even with her Finnish family.

I didn't tell [them about my conversion] directly; they've been left to deduce it from the changes that have happened to me. They've not said anything [negative] about it, and my mother even wanted to buy me a scarf, which was really nice. We were at Porvoo [open air] market [in Southern Finland], they have handmade woollen scarves there, and it was really kind of her because I think they think I've converted because of my husband.

Here the gift was particularly powerful, because it has embedded within it multiple levels of meaning. First, the scarf operated as an indicator of acceptance, of the continuance of positive family connections despite religious differences. Second, it expressed a form of parental care that the mother engages in. Third, the setting where the gift was purchased was highly significant. The small town of Porvoo is famous for artisanal arts and crafts objects, most of these being sold by their makers. The scarf was therefore not just any object, even when it existed as a commodity to be purchased. It figured as a valuable gift, both in its relatively high money value, and in the fact that it was hand-made and sold by the maker herself. These types of value helped to 'earmark' this gift as a oneoff and highly significant entity. The gift-giving of such a thing communicated powerfully the recipient's new socioreligious status and her mother's acceptance, and even appreciation, of it.

This was also an object with more symbolic resonance than pragmatic affordances. The mother did not know that the design rendered the scarf impractical as a hijab garment for everyday use. But the daughter was delighted to receive it, because of what it communicated to her about her mother's apparent acceptance of the conversion. This all resonates with Hénaff's (2010) clarification of one of Mauss's original points: a gift given for honorific purposes is not primarily to be consumed pragmatically (here, worn on the head), but is rather intended by the donor as a mark of respect in a process of alliance-building. By bestowing such a gift, one is 'honoring the existence and status of the other' (Hénaff, 2010: 153). Put another way, giving gifts in this manner is a means of granting and receiving 'regard' (Offer, 1997).

The actual pragmatic uses such an object can be put to are here secondary in relation to its symbolic and positive relationship-generating capacities. The mother's gift is not an instance of a donor seeking to manipulate a recipient, but rather of honouring her decisions and making peace with them. This is partly because it was Miriam's agency that drove the conversion, not the mother's. The latter felt she had to recognise the validity of her daughter's agency, and to render it compatible with ongoing mother-daughter and familial relationships. Here a scarf-gift was intended and framed as a bijab-gift (illustrating that these two entities are not necessarily the same). The gift failed to operate at the pragmatic level of Miriam actually being able to wear it as a hijab (which is what the non-Muslim mother seems to have intended). Nonetheless the gifted object successfully created bridges - between familial individuals, between religious affiliation and continued family membership, and between Muslim and non-Muslim groups and communities - that helped conduct all parties into the future in a constructive way. Here we see clearly the bonding capacities of such gifts, including across community and religious divisions.

\section{GIFTS, GENDER, PATRIARCHAL POWER AND FEMALE BONDING}

In this section we turn to consider two dimensions of the gendered nature of gifts: how gift-giving is a mechanism for the creation and reproduction of patriarchal relations within and outside of families, as well as a 
potential means for the creation of the types of solidarities among females that are irreducible to patriarchal dynamics.

Feminist authors have emphasised how gift-giving can be part of wider patriarchal complexes. For example, patriarchal social relations can compel women to give the 'gift' of care-giving - to children, male partners, elderly relatives, etc. - without financial payment and sometimes without any acknowledgement or thanks (Elder-Vass, 2015, Diprose, 2002). Recognition and reciprocation of women's gifts, both by men and wider families and communities, is seen to be prevented because of pervasive gender norms. Giving care, and other sorts of gifts, is widely regarded simply as something that women must just do, because their supposed 'nature' means that they are 'naturally' givers rather than receivers (Ashwin et al, 2013). Empirical research inspired by Hochschild (1989) who herself invokes Mauss - has indicated the delicate but often fraught 'economy of gratitude' that pertains within particular marriages and families. A woman's domestic labours may or may not be recognised as gifts by others, especially men, and reciprocation or non-reciprocation of those labours by family members both depends on, and creates, subtle power relations within the domestic setting (Pyke and Coltrane, 1996). Such research implies that in many settings, women are not only expected to give freely (of their time, emotional energies, etc.) to family members, but also possibly to receive certain gifts willingly, and perhaps enthusiastically too. At the least, a performance of willingness and enthusiasm might well be expected on the female recipient's behalf.

The case of Afra, a Shia Iraqi in her late twenties who is married to a man from the same ethnic community, illustrates how women are expected to 'give' to the husband's family in many ways, including to the benefit of the family's reputation among its peers. This is bound up with acts of the giving (by the family) and the receiving (by Afra) of clothing objects rendered as gifts. During the time leading up to her marriage, Afra recalls certain sartorial changes that were initiated by her decision to marry. The marriage was arranged between the two families, and was considered by Afra to be a union of the families, rather than just of two individuals.

It was through my aunt. His sister asked if I'm married. [...] Then they came to visit and asked for my hand and my father asked me what I think, do I agree? I asked what do you [both the parents] think, what kind of a family is it? The family is good and it has a good reputation, we knew this is a high-status family... [O]ne doesn't look at the boy what he's like, what he's done, but at the family. Because the family is responsible for the son. If he does something [wrong], the family takes the responsibility. I thought: that's a good family, the best family here in Finland, really good reputation, no one has as good a reputation here in Finland. So why not?

The putative husband enjoyed high social standing due to the exceptionally positive regard among Shia Iraqis for his long-established family, which was said to be descended from the prophet Muhammad himself. In a 'traditional' Islamic family setup, women are held particularly responsible for the upkeep of a family's reputation, by exhibiting to the wider community high levels of piety and modesty (Webster, 1984). Afra's husband's family sought to protect their reputation partly through female dress strategies.

In respect to dress we [i.e. Afra's original family] are different because they [the husband's family] all wear the abaya and the jilbab ${ }^{4}$. When a girl goes to school, they dress [like that] immediately. Now [one young daughter] wears trousers and a tunic but they slowly teach her to wear the abaya... But [in my family], mother wears the abaya and the jilbab but we [daughters] don't, we wear jeans and tunics and skirts. We are different [from the husband's family] in the sense that it's not so particular, not so necessary to have the abaya.

Afra's marriage made her a member of a higher status family than her own, transforming her life in various ways, including in sartorial terms. Her mother-in-law's gifts were highly significant in this regard.

When I got married, my mother-in-law gave me clothes; she had bought them abroad [probably in the Middle East] ... At that time, I didn't yet wear a black long robe, I had trousers and a top down here [indicates below mid-thigh] and then the scarf. This robe I started to wear when I got married. It was [my husband's family's] wish, and I said why not?

Such gifts as these are very ambiguous and potentially very powerful. While the mother-in-law solicited Afra's opinion about whether she would wear the more covering forms of dress that were being offered, Afra was hardly in a position to refuse to change her dress style. Such a refusal would have been costly to her, particularly in terms of the relationship to her mother-in-law. Refusal would have gone against the norms of the 'economy of gratitude'

${ }^{4}$ A jilbab is a 'full-length long-sleeved outer garment' (Tarlo 2005: 17).

$10 / 17$

(C) 2018 by Author/s 
pertaining in this particular diasporic ethnic group (Hochschild, 1989). ${ }^{5}$ The gifts came with an explicit request for the recipient to contribute to the family's maintenance of reputation, by dressing in a more covering way than hitherto, and operated as quite direct tools for enforcing the patriarchal family structure upon the new member. Afra's husband already enjoys a high reputation in the community provided by and through his family's high social standing. Afra is required by the family to contribute to reputation maintenance by modifying her dress and thereby herself too.

These demands could have been read as an imposition by Afra, but instead she found appealing elements in the situation. This is seen in how she narrates how her own family viewed her sartorial transformation.

$[\mathrm{My}]$ mother says, the more you make an effort for the religion, the more you work, the better level of Paradise you achieve ... Mother makes a comparison that I who wear the long robe get more [religious credit], because I'm young after all, want to dress fashionably, want to look pretty but I still cover myself for God. Because I fear God and put the long robe on, I get more virtues, I get more points. But [a woman who] dresses according to fashion, she gets less.

In making an appealing case for the sartorial, bodily, aesthetic and visual sacrifices she is required to make, Afra's mother tacitly works in co-operation with the mother-in-law, working upon Afra to accept the clothing gifts with apparent spontaneity and enthusiasm. This illustrates how the forms of social power inherent in and related to a gift can be reinforced by third parties, here Afra's mother. The apparently dyadic nature of the gift relationship can in fact be bound up with wider relations involving multiple actors, and it is this which sometimes contributes a great deal to the power dynamics of gifting. Through her mother's actions, Afra is made more likely to consent willingly, and even enthusiastically, to the patriarchal structure of both the family and of the wider ethnic community. Afra's consent in this regard, and the changed sartorial practices that go with it, are a kind of countergift voluntarily proffered by Afra to the mother-in-law, and to the family and community which stand behind her. In this way, a potential imposition is reworked, in both Afra's and her female relatives' perceptions, as a positive form and expression of piety, familial belonging and solidarity-building.

Forms of female bonding through clothing gifts need not necessarily involve these sorts of patriarchal power dynamics. The possibility of women exercising creative agency in gifting relationships has been identified by feminist authors (Weiner, 1976, 1992, Joy, 2013). Gifting may be a means for at least some women in some contexts to negotiate power relations, both with men and with other females (Komter, 1996). Some radical feminist positions claim that specifically 'female' forms of gift-giving are antithetical to what are regarded as essentially 'masculine' forms of exchange of objects. This implies that female-gifting, at least in some instances, may lack the obligatory-return dynamics identified by Mauss, instead being centred on unselfish forms of generosity expressed through gifts that have no expectation of reciprocation attached to them (Vaughn, 1997, Diprose, 2002). Such gifting can create specifically female forms of solidarity and relations of mutual enhancement, which may operate in relation to patriarchal structures in complicated ways, but which are irreducible to them (Cixous and Clément, 1986, Irigaray, 1996).

The case of Khadija is relevant here. She is a relatively recent Finnish convert in her sixties. She described a situation, some years before her conversion, where she had been the recipient of an elaborate gift from multiple donors. She had befriended many Somali families through her work for the City Council of Helsinki, and the community had learned to appreciate her efforts for their well-being. A group of women wanted to give her a garment to show their appreciation. This garment was described by Khadija as 'traditional Somali dress'. This is likely to refer to the Dirac, a full-length, sleeveless, rectangular dress-like garment, often made of translucent fabric (Isotalo, 2017: 272). The donors wanted to give the recipient a garment strongly associated with their ethnic group's identity.

Before having the garment made by a seamstress, the women came together to show the fabric to Khadija, to demonstrate that the garment she was to receive was new and made specially for her, a particular kind of 'earmarking'. According to Khadija, this sort of act is crucial for Somali gift-giving: it would be unacceptable to

${ }^{5}$ The interview data yielded no instances of outright refusals of gifts. Nonetheless, the interviewer (Almila) was sometimes offered cheaply-made scarves, that could be worn as hijabs, by those interviewees particularly interested in converting non-Muslims to Islamic observance. Such women often kept supplies of such scarves in their homes, to be given as gifts to both Muslim and non-Muslim acquaintances, presumably with the purpose of sparking an interest in covering the head, and therefore leading eventually to conversion to the faith. In these cases, the interviewer accepted the gift, for the sake of building a rapport, but did not subsequently wear it or pursue any interest in conversion. But the interviewer did not discard the garments. The gift was accepted but not reciprocated in the manner the donor would probably have wanted. Third-party engagement also happened in this regard: wearing 'modest' forms of dress (but not covering the hair) in Islamic events during the fieldwork often resulted in openly expressed approval, by Finnish converts in particular, for the dress style chosen by the interviewer.

C 2018 by Author/s 
give a second-hand gift for special occasions. Even though the fabric had been purchased as a commodity, the bespoke and artisanal nature of the garment itself meant that it had already been significantly de-commoditised by collective agency before the point in time that it was given, thus rendering it potentially particularly powerful in terms of the recipient's emotional response to it.

The special nature of the gift was also augmented and dramatized through a ceremonial element. Arriving together as a group, to present to the recipient the material of which the garment was to be made, bound all the donor women into the gift itself. All their individual personalities were melded together to become integral parts of the gift. The gift was thereby rendered unlikely to become a commodity at some point in the future, so charged with significance for the recipient was it. This sort of giving act is not reducible to patriarchal social structures, even if the donors live within highly patriarchal communities. By making the gift communicate 'this is a Somali garment', 'it is from all of $u s^{\prime}$, and 'it is made only for you', the women acknowledged Khadija's special status for them: as a non-member of the group that nonetheless the group honours because of the care - a kind of gift in itself - that she has shown them. The donors likely viewed their gift as a counter-gift for all the services Khadija had rendered them in her professional work.

Receiving this gift was one element in Khadija having a very positive view of the Somali community, which in turn encouraged her later to convert to Islam. This sartorial gift was not a bijab-gift like others mentioned above, but it nonetheless played a role in her conversion career. Khadija was under no pressure to convert, conversion being wholly a matter of her own agency. The gift here was not patriarchal, at least in any obvious or direct sense. It did encourage her to become a Muslim who has very strong connections to the Somali community, which exhibits strong patriarchal features. Nonetheless, the gift and Khadija's acceptance of it are not at all simple or direct expressions of patriarchy.

\section{CHARITABLE GIVING - BETWEEN THE RELIGIOUS AND THE SECULAR}

The explicitly 'religious' dimensions of gifts and gift-giving are aspects of Mauss's thinking that have been clarified by Hénaff (2010). Most attention by subsequent scholars has focused on one of two types of gifting, namely the giving of gifts in direct inter-personal interactions, which in ideal-typical terms are (apparently) symmetrical and horizontal in nature. But there is a second type too, where a person, often explicitly acting on behalf of a group, gives gifts to the gods or other supernatural entities. Such gifts may or may not be construed by actors as sacrifices. The gifting relationship here is vertical and asymmetrical in nature, with an actor who perceives themselves to be lower in a religious hierarchy offering gifts to higher entities. The subterranean point of such gifting when it is done on the behalf of a group is to create group solidarity, through establishing intimate bonds with the supernatural entities to which the group may largely owe its identity as a group in the first place.

Hénaff (2010) points out that the 'religious' type of gifting may in some cases permeate the inter-personal type. Gifts exchanged between people for intentionally 'religious' purposes, of some sort or another, display this dual feature. The everyday gift and act of gifting are imbued with a higher level of significance, concerning extramundane and 'sacred' matters. Parry (1986) notes that in many religiously-based groups, donors are required to act in the belief that they must not expect any worldly return on their gift-giving, in terms of accruing some material kind of advantage. But they may tacitly expect - and may be allowed by group norms to expect - some sort of credit in the after-life, if such a thing is believed in.

This points us in the direction of dealing with the complex motivations involved in the types of gift-giving defined by actors as acts of 'charity', whether in explicitly religious or secular forms, or in a mixture of the two (Ostrower, 1997). Giving charitable gifts either directly to known individuals, or to unknown individuals through donating to a charitable organisation, can strongly inform a donor's self-perception, including as a putatively virtuous person (Silber, 1998). Sociologists have shown how acts of charitable giving can also help to establish or reproduce the high social status of a donor (Collins, 1988). This is especially the case when some sort of audience is involved. Approval from a peer group potentially acts as a stronger means of recognising the donor's virtue than does the gratitude of the gifts' actual recipients. In the case of unknown recipients, sentiments of gratitude may never actually be vocalised, or may only be ventriloquised by the officials of the charitable organisation which arranged the donation (Blau, 1986).

Muslim women have different but interlocking reasons for giving away clothes. Some reasons are to do with charity, and therefore the act of giving away is a kind of gift-giving (captured in the phrase 'donating to charity'). Charitable giving is one of the foundations of the Islamic faith, expressed in the Five Pillars of Islam. Zaynab, a Somali in her late twenties, sends parcels of old clothes to Somalia. ${ }^{6}$ Charitable giving was pleasurable for her, possibly gaining her peer approval in her community, regarding her perceived religious credentials.

${ }^{6}$ For what may happen in particular recipient contexts to clothing gifts, see Hansen (2000). 
Yet Zaynab's thinking was also very much shaped by environmental concerns, which are secular in nature. She sought to reduce her meat consumption - 'I don't really need it' - and was also highly conscious of the environmental issues thrown up by rapidly-changing fashion cycles. While her consumption was notably informed by secular environmental considerations, her giving away of garments was more shaped both by religious considerations of charitable gifting, and by a sense of trans-national community belonging and solidarity with the homeland. Zaynab's reality is one where her garment-related and gifting activities are thoroughly underpinned by a mixture of religious and secular concerns, which one may take to be typical of many young Muslim adults in diaspora contexts (Moors and Tarlo, 2013).

Nura, already encountered above, illustrates a different way in which religious and secular concerns inform, in complex ways, sartorial and gifting practices. She considers her whole attire as involving obedience to God. This makes the possession of specific garments, including hijab garments, relatively unimportant to her.

In my opinion the clothes aren't the thing, but that you obey God. If a garment serves that purpose it becomes important. Not so that you're attached to material, but you wear certain [clothes] because you're a Muslim and you obey God and that's it. Nothing else. In my opinion Muslims shouldn't cling to anything worldly. You wear what you wear because Allah has told you to and you obey God, and there's no greater reason.

One might expect, on the basis of such sentiments, Nura to discard clothes through Islamic charitable giving. But she does not. Instead, while she considers it a religious duty not to be overly attached to worldly goods, she also uses secular language about 'recycling' clothes. However, this is not necessarily for environmental reasons.

I've also learned to recycle the clothes I don't wear anymore so that my closets won't be stuffed. So that I won't feel guilty for having closets full of clothes.

Just as religious and secular arguments are often mixed together when Muslim women reject overly 'fashionable' garments (Moors and Tarlo, 2013), so too when giving away one's garments, religious rationales may get tied up with secular language and notions. While Nura's sense of guilt about having 'too many' clothes is partly induced by religious considerations, her reaction to such a situation is more secular in nature. Instead of charitably donating garments for religious reasons to those in need, she says she 'recycles' them. 'Recycling' of garments is very much part of the rhetoric today of the global capitalist system and putative reforms of, or alternatives to, it (Claudio, 2007). Nura's choice of words shows that a very religious person may yet understand what they are doing, when they discard clothing and other material objects, in very secular terms. Those secular terms may stimulate ways of giving away clothes, or other goods, which seem in this case to trump charitable giving for religious reasons.

As Nura wears both highly 'religious' garments and 'normal' (in Finnish terms) clothes underneath them, her recycling could involve giving away either type. She did not specify in the interview whether the latter category was more likely to be deemed 'recyclable' than the former - an intriguing gap in this research which merits further investigation. Nonetheless, there is a further irony here. When Nura 'recycles', she is most likely taking the clothes to a public collection-point for unwanted clothing items. Most such repositories in Finland are run by charities, some of which are secular while some are Christian. Therefore Nura's 'recycling' might well become, presumably unintentionally and unknowingly, in one sense an act of secular or Christian charitable gift-giving.

\section{CONCLUSION}

The central point of this paper has been to demonstrate that hijabs and gifts can throw new light on each other when they are considered in tandem. Gift theory can give us new insights into the wearing of hijabs, while examining hijabs given and received as gifts can tell us novel things about the nature of gifts. Muslim women operate today in social contexts where both hijab-related and gift-related practices are notably multi-layered. Focusing on gifting activities can generate new perspectives for understanding the multiple layers of meaning and significance that are involved in the wearing of a hijab, including in diasporic contexts. Focusing on the bijab-gift and related sartorial objects, which are usually ambiguous in nature, gives us a constructive way into investigating complicated and often ambivalent issues to do with religion, community, gender, clothing, fashion and diaspora.

The giving of hijab-related garments as gifts is primarily, if not exclusively, a matter among women only, men being excluded from such processes. This possibly complicates the connections between such gift-giving practices and patriarchal social structures, for men's actions are not directly involved in these matters. How male members of families and communities are connected to such practices remains to be investigated. Nonetheless, we have seen how female members of families, and more broadly of specific ethnic communities, can subtly but profoundly influence, through giving certain garments as gifts, what individual recipient women do vis-à-vis the wearing of hijabs. Donors can shape whether recipients will wear a hijab or not, including in relation to converting to Islam. 
They can also impact upon which type of hijab will be worn by recipients, and what kinds of religious observance - stricter or looser, more conservative or more liberal - will accordingly structure both the recipient's interior sense of selfhood and also their exterior look and conduct.

The existing literature on Islamic veiling recognises ambivalences in relation to why and how many women adopt hijabs, and the reasons they give for such adoption. Women are led to understand that the adoption must be an apparently wholly voluntary act of free will, while simultaneously they are told by families, peers and religious authorities that the adoption is strongly desirable, if not in fact compulsory (Almila, 2018). The potential contradiction here may be particularly prone to surface in diasporic contexts, which are often marked by the complicated interplay of religious and secular logics and forms of justification. This paper has shown the important role of gifts and gift-giving in such processes, a feature that has not been much remarked on before, if at all. Donors of hijab-gifts can influence the precise manners in which recipients embrace the hijab and make sense of their adoption of it, sometimes coming to understand the latter as a voluntary act to be engaged in enthusiastically.

We can say that hijab-related gifts and gifting practices can, at least under certain circumstances, work to smooth out, obscure and neutralise perceptions and feelings of ambivalence, of the sort noted above, that may pertain among diasporic Muslim women. In a paradoxical way, then, it may be that it is the hijab-gift's ambiguous nature itself which allows it to work as a resource for neutralising potential ambivalences, both within the thoughts and perceptions of recipient women, and in the social relations that pertain between donors and receivers. Such relations are themselves made possible, or at least strongly influenced by, the very act of gift-giving itself. Giving an ambiguous object may be a way of - partly or wholly - eliminating ambivalences, both in the recipient's mind about the wearing of the hijab, and also in her relations with the donor, as well as with the family and community members who stand behind the latter.

In line with contemporary economic sociology, we want to emphasise that while bijab-gifts have the potential to exhibit such capacities, there is nothing automatic about the realisation of such potentials, for the latter depends upon contingent empirical circumstances. We hypothesise that the stronger familial and community bonds are, and the more decidedly patriarchal are social relations within specific families and ethnic and religious groups, the greater likelihood there is of hijab-gifts working to neutralise perceived ambivalences, about hijabs and related matters, experienced by recipient women. Conversely, precisely because of their ambiguous nature, such gifts could also potentially beigbten and dramatize feelings of ambivalence, both within the recipient's mind, and between her and the donor, and the groups who stand behind the latter. This may be more likely in contexts marked by looser community and familial bonds, and less marked patriarchal structures and attitudes. Although such a scenario was not captured in our data, empirical examination of such possible scenarios in other diasporic contexts would be a productive pathway for future research.

Despite these open-ended questions, we can conclude that a bijab-gift is always potentially a very powerful object, as well as a subtle one, tied up in various ways with different sorts of power relations. Its capacity to generate relations between individuals, and to influence individuals' actions, ultimately rests in its complex nature and its deep, multi-layered ambiguity. The giving and receiving of such gifts is marked by multiple ambivalences, which can be handled by women in different ways. Specific forms of social power can be created, nurtured, maintained, expressed, thematised, obscured, neutralised, modified, and perhaps sometimes resisted, in and through the social relations that the giving and receiving of such objects involves and makes possible. Gift theory since Mauss has been very aware of any gift object's potential powers and affordances. Consideration of the case of the bijab-gift adds various more layers to those original insights. It allows for new and more precise delineations of the multiple factors that, in a globalized world condition marked by diasporic situations and world-spanning flows of commodities, together constitute the burgeoning complexity of the often strikingly manifold and subtle nature of gifts and the social relations they inspire.

\section{REFERENCES}

Addo, P.-A. and Besnier, N. (2008). When Gifts Become Commodities: Pawnshops, Valuables, and Shame in Tonga and the Tongan Diaspora. Journal of the Royal Anthropological Institute, 14(1), 39-59. https://doi.org/10.1111/j.1467-9655.2007.00477.x

Adloff, F. and Mau, S. (2006). Giving, Social Ties, and Reciprocity in Modern Society. European Journal of Sociology, 47(1), 93-123. https://doi.org/10.1017/S000397560600004X

Ahmed, L. (2011). A Quiet Revolution: The Veil's Resurgence, from the Middle East to America. New Haven: Yale University Press.

Almila, A. (2017). Introduction: The Veil Across the Globe in Politics, Everyday Life and Fashion, in A. Almila, and D. Inglis (eds.), The Routledge International Handbook to Veils and Veiling Practices (pp. 1-25). London: Routledge. https://doi.org/10.4324/9781315613734

-- (2018). Veiling in Fashion: Space and the Hijab in Minority Communities. London: I. B. Tauris. 
Appadurai, A. (1986). Commodities and the Politics of Value, in A. Appadurai (ed.), The Social Life of Things: Commodities in Cultural Perspective (pp. 3-63). Cambridge: Cambridge University Press. https:// doi.org/10.1017/CBO9780511819582.003

Ashwin, S., Tartakovskaya, I., Ilyina, M., and Lytkina, T. (2013). Gendering Reciprocity: Solving a Puzzle of Nonreciprocation. Gender and Society, 27(3), 396-421.

Bataille, G. (1991). The Accursed Share: An Essay on General Economy. Volume 1: Consumption. New York: Zone Books.

Belk, R. W. (1988). Possession and the Extended Self. Journal of Consumer Research, 15, 139-68. https://doi.org/10.1086/209154

Berking, H. (1999). Sociology of Giving. Thousand Oaks: Sage.

Bird-David, N. and Darr, A. (2009). Commodity, Gift and Mass-Gift: On Gift-Commodity Hybrids in Advanced Mass Consumption Cultures. Economy and Society, 38, 304-325. https:// doi.org/10.1080/03085140902786777

Blau, P. M. (1986). Exchange and Power in Social Life. New Brunswick: Transaction.

Bourdieu, P. (1977). Outline of a Theory of Practice. Cambridge: Cambridge University Press. https:// doi.org/10.1017/CBO9780511812507

-- (2000). Pascalian Meditations. Cambridge: Polity.

Bracken, C. (1997). The Potlatch Papers: A Colonial Case History. Chicago: University of Chicago Press.

Caillé, A. (2005). Esquisse d'une Analytique du Don, in Dé-penser l'économique, Paris: La Découverte/MAUSS.

Callon, M. and Law, J. (2005). On Qualculation, Agency, and Otherness. Environment and Planning D: Society and Space, 23, 717-33. https://doi.org/10.1068/d343t

Caplow, T. (1982). Christmas Gifts and Kin Networks. American Sociological Review, 47(3), 383-392. https://doi.org/10.2307/2094994

Carrier, J. G. (1991). Gifts, Commodities and Social Relations: A Maussian view of exchange. Sociological Forum, 6(1). https://doi.org/10.1007/BF01112730

-- (1995). Gifts and commodities: Exchange and Western capitalism since 1700. London: Routledge.

Chanial, P. (2014). The Gift and Care, Reuniting a Political Family? Revue du MAUSS, 25 Juin 2014 http://www.journaldumauss.net/./?The-Gift-and-Care-1129

Cheal, D. J. (1988). The Gift Economy. New York, Routledge.

Cixous, H. and Clément, C. (1986). The Newly Born Woman. Minneapolis: University of Minnesota Press.

Claudio, L. (2007). Waste Couture: Environmental Impact of the Clothing Industry. Environmental Health Perspectives, 115(9), A449-A454. https://doi.org/10.1289/ehp.115-a449

Collins, R. (1988). Women and Men in the Class Structure. Journal of Family Issues, 9, 27-50. https://doi.org/10.1177/019251388009001003

Csikszentmihalyi, M. and Rochberg-Halston, E. (1981). The Meaning of Things. Cambridge: Cambridge University Press. https:// doi.org/10.1017/CBO9781139167611

Derrida, J. (1992). Given Time: 1. Counterfeit Money. Chicago: University of Chicago Press.

Douglas, M. (1990). Foreword, in M. Mauss, The Gift: The Form and Reason for Exchange in Archaic Societies (pp. ixxxiii), London: Routledge.

Douglas, M. and Isherwood, B. (2006). The World of Goods: Towards an Anthropology of Consumption. London: Routledge.

Diprose, R. (2002). Corporeal Generosity: On Giving with Nietžsche, Merleau-Ponty, and Levinas. New York: SUNY Press.

Elder-Vass, D. (2015). Free Gifts and Positional Gifts: Beyond Exchangism. European Journal of Social Theory, 18(4), 451-468.

El Guindi, F. (1999). Veil: Modesty, Privacy and Resistance. Oxford: Berg.

Firth, R. (1967). Themes in Economic Anthropology: A General Comment, in R. Firth (ed.) Themes in Economic Anthropology (pp. 1-28). London: Tavistock.

Folbre, N. (2001). The Invisible Heart: Economics and Family V alues. New York: New Press.

Franks, M. (2000). Crossing the Borders of Whiteness? White Muslim Women Who Wear the Hijab in Britain Today. Ethnic and Racial Studies, 23:5, 917-29. https://doi.org/10.1080/01419870050110977

Garces, C. and Jones, A. (2009). Mauss Redux: From Warfare's Human Toll to "L'Homme Totale". Anthropological Quarterly, 82(1), 279-309. https:// doi.org/10.1353/anq.0.0046

Godbout J. (2000). Homo Donator versus Homo Oeconomicus, in A. Vandevelde (ed.), Gifts and Interests (pp. 2346), Leuven: Peeters.

Godbout, J. and Caille', A. (1998). The World of the Gift. Montreal: McGill-Queen's University Press.

Godelier, M. (1996). L'Énigme du Don. Paris: Fayard.

Gökarrksel, B. and Secor, A. (2013). Transnational Networks of Veiling-Fashion between Turkey and Western Europe, in E. Tarlo and A. Moors (eds), Islamic Fashion and Anti-Fashion, 157-167. London: Bloomsbury.

Gooren, H. (2007). Reassessing Conventional Approaches to Conversion: Toward a New Synthesis. Journal for the Scientific Study of Religion, 46(3), 337-353. https:// doi.org/10.1111/j.1468-5906.2007.00362.x 
Gouldner, A. W. (1960). The Norm of Reciprocity: A Preliminary Statement. American Sociological Review, 25, 161178. https://doi.org/10.2307/2092623

Graeber, D. (2001). Toward an Anthropological Theory of V alue: The False Coin of our Own Dreams. New York: Palgrave. https://doi.org/10.1057/9780312299064

Gregory, C. (1982). Gifts and Commodities. London: Academic Press.

Hansen, K. T. (2000). Saluala: The World of Second-Hand Clotbing and Zambia. Chicago: University of Chicago Press.

Hénaff, M. (2010). Mauss et l'invention de la Réciprocité. Revue du MAUSS, 36(2), 71-86.

Herrmann, G. M. (1997). Gift or Commodity: What Changes Hands in the U. S. Garage Sale? American Ethnologist, 24(4), 910-930.

Hochschild, A. R. (1989). The Economy of Gratitude, in D. Franks and D. McCarthy (eds.), Original Papers in the Sociology of Emotions (pp. 95-113). New York: JAI Press.

Hogan, E. N. (2010). Jewels of the Occupation: Gold Wedding Jewelry in the West Bank. Journal of Palestine Studies, 39(4), 43-49. https://doi.org/10.1525/jps.2010.XXXIX.4.43

Hyde, L. (1983). The Gift: Imagination and the Erotic Life of Property. New York: Vintage Books.

Irigaray, L. (1996). I Love to You. Sketch for a Felicity within History. New York: Routledge.

Isotalo, A. (2017). Constructions and Reconstructions of 'Appropriate Dress' in the Diaspora, in A. Almila and D. Inglis (eds.). The Routledge International Handbook to Veils and Veiling Practices (pp. 267-277). London: Routledge.

Jones, C. (2010a). Images of Desire: Creating Virtue and Value in an Indonesian Islamic Lifestyle Magazine. Journal of Middle East Women's Studies, 6(3), 91-117. https:// doi.org/10.2979/MEW.2010.6.3.91

-- (2010b). Materializing Piety: Gendered Anxieties about Faithful Consumption in Contemporary Urban Indonesia, American Ethnologist, 37(4), 617-637. https://doi.org/10.1111/j.1548-1425.2010.01275.x

Joy, M. (2013). Introduction, in M. Joy (ed.), Women and the Gift (pp. 1-52). Bloomington: Indiana University Press.

Keane, W. (2006). Subjects and Objects, in C. Tilly (ed.), Handbook of Material Culture (pp. 197-202). London: Sage.

Kilıçbay, B. and Binark, M. (2002). Consumer Culture, Islam and the Politics of Lifestyle: Fashion for Veiling in Contemporary Turkey. European Journal of Communication, 17(4), 495-511. https://doi.org/10.1177/02673231020170040601

Komter, A. E. (1996). Reciprocity as a Principle of Exclusion. Sociology, 30(2), 299-316.

-- (2005). Social Solidarity and the Gift. Cambridge: Cambridge University Press. https://doi.org/10.1177/0038038596030002006

Kopytoff, I. (1986). The Cultural Biography of Things: Commoditization as Process, in A. Appadurai (ed.), The Social Life of Things: Commodities in Cultural Perspective (pp. 64-91). Cambridge: Cambridge University Press. https://doi.org/10.1017/CBO9780511819582.004

Kosalka, D. L. R. (1999). Historian Underground: Making History Relevant For Life: Georges Bataille and the Notion of Gift. http:/ / www.sauer-thompson.com/essays/Bataille\&theGift.doc

Lainer-Vos, D. (2013). The Practical Organization of Moral Transactions: Gift Giving, Market Exchange, Credit, and the Making of Diaspora Bonds. Sociological Theory, 31(2), 145-167. https://doi.org/10.1177/0735275113489123

-- (2014). Brothers' Keepers: Gift Giving Networks and the Organization of Jewish American diaspora nationalism. Socio-Economic Review, 12(3), 463-488. https://doi.org/10.1093/ser/mwu003

Leacock, E. B. (1981). Myths of Male Dominance. New York: Monthly Review Press.

Lindholm, C. (2010). Snapshot: The Abayeh in Qatar, in G. Vogelsang-Eastwood (ed.) Berg Encyclopedia of World Dress and Fashion, Volume 5: Central and Southwest Asia (pp. 252-254). Oxford: Berg.

Mauss, M. (1970). The Gift: Forms and Functions of Exchange in Archaic Societies. London: Cohen \& West.

Mirowski, P. (2001). Refusing the gift, in S. Cullenberg, J. Amariglio and D. F. Ruccio (eds.), Postmodernism, Economics and Knowledge (pp. 431-58). London: Routledge. https://doi.org/10.4324/9780203410707.ch21

Moghissi, H. (2003), Diaspora of Islamic Cultures: Continuity and Change. Canada's Journal of Refugees, 11(2), 11419.

Moors, A. and Tarlo, E. (2013). Introduction, in E. Tarlo and A. Moors (eds.), Islamic Fashion and Anti-Fashion (pp. 1-29). London: Bloomsbury.

Offer, A. (1997). Between the Gift and the Market: The Economy of Regard. Economic History Review, 3, 450-76. https://doi.org/10.1111/1468-0289.00064

Osteen, M. (2002). Introduction, in M. Osteen (ed.), The Question of the Gift: Essays across Disciplines (pp. 1-41). London: Routledge.

Ostrower, F. (1997). Why the Wealthy Give: The Culture of Elite Philanthropists. Princeton: Princeton University Press.

Parry, J. (1986). The Gift, The Indian Gift, and "the Indian Gift". Man, 21, 453-73. https://doi.org/10.2307/2803096 
Parry, J. and Bloch, M. (1989). Introduction: Money and the Morality of Exchange, in J. Parry and M. Bloch (eds.), Money and the Morality of Exchange (pp. 1-32). Cambridge: Cambridge University Press. https://doi.org/10.1017/CBO9780511621659.001

Pyke, K. and Coltrane, S. (1996). Entitlement, Obligation and the Gratitude in Family Work. Journal of Family Issues, 17(1), 60-82. https:/ / doi.org/10.1177/019251396017001005

Pyyhtinen, O. (2014). The Gift and its Paradoxes. Farnham: Ashgate.

Rey, T. (2008). Bourdieu on Religion: Imposing Faith and Legitimacy. London: Acumen.

Sahlins, M. (1972). Stone Age Economics. Chicago: Aldine-Atherton.

Sandıkcı, Ö. and Ger, G. (2005). Aesthetics, Ethics and Politics of the Turkish Headscarf, in S. Küchler and D. Miller (eds.) Clothing as Material Culture (pp. 61-82). Oxford: Berg. https:/ /doi.org/10.2752/9780857854056/CLMATCULT0007

-- (2007). Constructing and Representing the Islamic Consumer in Turkey. Fashion Theory, 11(2/3), $189-210$.

Sandıkcı, Ö. and Omeraki, S. (2007). Islam in the Marketplace: Does Ramadan Turn into Christmas? Advances in Consumer Research, 34, 610-615.

Schwartz, B. (1967). The Social Psychology of the Gift. American Journal of Sociology, 73, 1-11. https://doi.org/10.1086/224432

Sherry, Jr., J. F., McGrath, M. A. and Levy, S. J. (1993). The Dark Side of the Gift. Journal of Business Research, 28, 225-244.

Shershow, S. C. (2005). The Work and the Gift. Chicago: University of Chicago Press.

Silber, I. F. (1998). Modern Philanthropy: Reassessing the Viability of a Maussian Perspective, in W. James and N. J. Allen (eds.) Marcel Mauss: A Centenary Tribute (pp. 134-50). Oxford: Berghahn.

-- (2009). Bourdieu's Gift to Gift Theory: An Unacknowledged Trajectory. Sociological Theory, 27, $173-90$. https://doi.org/10.1111/j.1467-9558.2009.01342.x

Skågeby, J. (2013). The Performative Gift. communication+1, 2, Article 7.

Strathern, M. (1988). The Gender of the Gift: Problems with Women and Problems with Society in Melanesia. Berkeley: University of California Press.

Tarlo, E. (2005). Reconsidering Stereotypes: Anthropological reflections on the jilbab controversy. Anthropology Today, 21(6), 13-7.

Testart, A. (1998). Uncertainties of the 'Obligation to Reciprocate': A Critique of Mauss, in W. James and N. J. Allen (eds.), Marcel Mauss: A Centenary Tribute (pp. 97-110). Oxford: Berghahn.

Titmuss, R. (1997). The Gift Relationship. New York: New Press.

Vaughn, G. (1997). For-Giving: A Feminist Criticism of Exchange. Austin: Plain View.

Webster, S. K. (1984). Harīm and Hijāb: Seclusive and Exclusive Aspects of Traditional Muslim Dwelling and Dress. Women's Studies International Forum, 7(4), 251-7. https:/ / doi.org/10.1016/0277-5395(84)90050-5

Weiner, A. (1976). Women of V alue, Men of Renown: New Perspectives in Trobriand Exchange. Austin: University of Texas Press.

-- (1992). Inalienable Possessions: The Paradox of Keeping-While-Giving. Berkeley: University of California Press. https://doi.org/10.1525/california/9780520076037.001.0001

Weinberger, M. F. and Wallendorf, M. (2011). Intracommunity Gifting at the Intersection of Contemporary Moral and Market Economies. Journal of Consumer Research, 39, 74-92. https:/ / doi.org/10.1086/662198

Zelizer, V. A. (1996). Payments and Social Ties. Sociological Forum, 11, 481-95. https://doi.org/10.1007/BF02408389

-- (2000). How Do We Know Whether a Monetary Transaction Is a Gift, an Entitlement, or Compensation? in A. Ben-Ner and L. Putterman (eds.), Economics, Values, and Organization (pp. 329-33). Cambridge: Cambridge University Press. 